\title{
A Novel Long-Term Graves' Disease Animal Model Confirmed by Functional Thyrotropin Receptor Antibodies
}

\author{
Tanja Diana $^{a}$ Hans-Peter Holthoff $^{b}$ Julia Fassbender ${ }^{b}$ Christian Wüster $^{c}$ \\ Michael Kanitz $^{\mathrm{a}} \quad$ George J. Kahaly $^{\mathrm{a}}$ Martin Ungerer ${ }^{\mathrm{b}}$ \\ ${ }^{a}$ Molecular Thyroid Research Laboratory, Department of Medicine I, Johannes Gutenberg University (JGU) \\ Medical Center, Mainz, Germany; ${ }^{\mathrm{b}}$ AdvanceCor GmbH, Martinsried, Germany; ${ }^{\mathrm{C}}$ Endocrine Laboratory and Practice \\ Prof. Wüster, Mainz, Germany
}

\section{Keywords}

Long-term Graves' disease animal model · Graves' disease · Thyrotropin receptor - TSHR-stimulating antibodies .

TSHR-blocking antibodies · Cell-based bioassays

\begin{abstract}
Introduction: A novel long-term murine model for Graves' disease (GD) using repeated, long-term immunizations with recombinant adenovirus expressing the extracellular A-subunit of the human thyrotropin receptor (Ad-TSHR) was applied to evaluate the functional anti-TSHR-antibody (TSHRAb) profile. Methods: BALB/c mice received 7 immunizations with either $10^{10}$ plaque-forming units of Ad-TSHR or control Ad-GFP. Naïve (nonimmuized native) mice were also studied. Three 3-weekly immunizations were followed by 4-weekly boosts until the 7th immunization. Blocking (TBAb) and stimulating (TSAb) TSHR-Ab were measured with bioassays. Assay cut-offs for TBAb/TSAb were at 34\% inhibition and a specimen-to-reference ratio (SRR) of $140 \%$. Results: Nineteen (8 Ad-TSHR-, 4 Ad-GFP-immunized, and 7 native) mice were investigated. All native mice were negative for TSHRbinding inhibitory immunoglobulins (TBII) prior to immunization. Native and Ad-GFP mice were negative in weeks 17
\end{abstract}

karger@karger.com www.karger.com/etj

C) 2020 European Thyroid Association Published by S. Karger AG, Basel and 27 for TBll and TBAb/TSAb. In native mice, the free thyroxine (fT4) levels (median [25th percentile; 75 th percentile]) were in the upper normal range $(1.2 \mathrm{ng} / \mathrm{mL}[1.1 ; 1.6])$ prior to immunization, at weeks $17(2.2 \mathrm{ng} / \mathrm{mL}[2.1 ; 2.4])$ and $27(1.4$ $\mathrm{ng} / \mathrm{mL}[1.1 ; 1.7])$, respectively. In contrast, in Ad-TSHR-immunized mice, fT4 values were markedly increased at weeks 17 $(4.4 \mathrm{ng} / \mathrm{mL}[3.9 ; 6])$ and $27(4.5 \mathrm{ng} / \mathrm{mL}[4.2 ; 6])$ compared to those in Ad-GFP mice $(2 \mathrm{ng} / \mathrm{mL}[1.8 ; 2.1]$ and $1.4 \mathrm{ng} / \mathrm{mL}[1.1$; $1.6])$, respectively $(p=0.0008, p=0.001)$. In contrast, at week 17 , in Ad-TSHR mice, the mean TBII, TBAb, and TSAb levels were $40 \mathrm{IU} / \mathrm{L}(40 ; 40) ; 62 \%$ inhibition $(38 ; 69)$, and $116 \%$ SRR $(97 ; 185)$, respectively; at week 27 , they were 40 IU/L $(39 ; 40)$; $65 \%$ inhibition $(34 ; 80)$ and $95 \%$ SRR $(63 ; 187)$, respectively. Three serum samples from Ad-TSHR mice (38\%) demonstrated dual TBAb/TSAb positivity. Conclusions: TBAb/TSAb were highly prevalent in Ad-TSHR-immunized mice, thus confirming the successful establishment of a novel, longterm murine model for GD. All TBAb- and TSAb-positive AdTSHR-immunized mice were TBII-positive. Thus, the binding immunoassay did not differentiate between TSHR-Ab functionality.

(C) 2020 European Thyroid Association Published by S. Karger AG, Basel

G.J.K. and M.U. share senior authorship. 


\section{Introduction}

Graves' disease (GD) is the most prevalent organspecific autoimmune disorder and the primary cause of hyperthyroidism. GD is a well-characterized autoimmune thyroid disease with a large number of known susceptibility genes [1]. The autoimmune process that occurs in GD involves both T cells and B cells, which results in the production of autoantibodies to the TSH receptor (TSHR-Ab). The clinical phenotype of GD is induced by unregulated stimulation of thyroid cells and TSHR-stimulating Ab (TSAb) that activate the TSHR [2-7] or as antagonist, blocking (TBAb) the activity of the natural ligand thyrotropin (TSH) $[8,9]$. TSAb is a sensitive, specific, and reproducible biomarker for GD; it reliably predicts the response to medical therapy and correlates well with disease severity and extra thyroidal manifestations, i.e., thyroid eye disease [6, 10-14].

Various attempts have been made to model human GD in mice, i.e., by administration of plasmid TSHR DNA via electroporation [15-17] or intramuscular injection [18, 19], transfected fibroblasts [20], and plasmid or adenoviral immunizations with the extracellular Asubunit of the human TSHR [21]. The application of the adenovirus was more potent and efficient, in comparison to electroporation which caused relevant mortality [22]. A long-term murine model for human GD was established using continuing immunizations with the recombinant adenovirus expressing the TSHR A domain gene (Ad-TSHR). Long-term persistence of models using adenoviral gene transfer has not been clearly described in previous studies. Prolongation of the protocol on 3 adenoviral induced immunizations over 6 weeks and measurements after 20 weeks instead of 10 weeks also led to disease induction [23]. However, prolongation of adenoviral TSHR immunizations by using a novel protocol in which regular injections was continued for 9 months and led to permanent $\mathrm{Ab}$ production in mice [24].

In this study, the functional TSHR-Ab (TSAb and $\mathrm{TBAb}$ ) profile, levels of TSHR-binding inhibitory immunoglobulins (TBII) and free thyroxine (fT4) serum levels were measured and evaluated in a novel, longterm murine model for human GD using 7 repeated immunizations over 27 weeks with Ad-TSHR. These values were compared to those in mice immunized with the adenovirus expressing only the reporter gene green fluorescent protein (Ad-GFP) and to native nonimmunized mice.

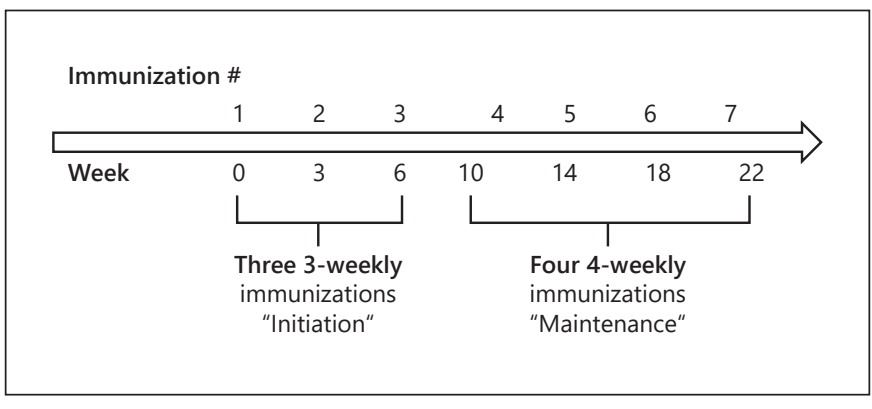

Fig. 1. Immunization schedule. Seven immunizations of either $10^{10}$ plaque-forming units of the adenovirus expressing the A-subunit of human TSHR (Ad-TSHR) or green fluorescent protein (Ad-GFP). For comparison, native nonimmunized mice were also studied.

\section{Material and Methods}

\section{Animal Studies}

Female BALB/c mice were delivered from Charles River at the age of 5 weeks and were adapted for at least 1 week to start experiments at 6 weeks. All mice were kept under standard housing conditions $\left(23 \pm 2{ }^{\circ} \mathrm{C}\right.$ and $55 \pm 10 \%$ relative humidity). Mice were randomly assigned into verum immunization groups, receiving $10^{10}$ plaque-forming units (pfu) of Ad-TSHR (first 289 amino acids of the human TSHR) or $10^{10} \mathrm{pfu}$ of Ad-GFP. For comparison, age-matched, native, nonimmunized mice were studied. For immunization, mice were anesthetized with isoflurane (introduction dose $5 \%$ and maintenance dose $1.5-2 \%$ ) and placed on a heating pad. The adenovirus was injected into the left and right femoral muscles at a volume of $25 \mu \mathrm{L}$ each. For blood withdrawal, mice were moved to a restrainer. A total of $100 \mu \mathrm{L}$ of blood was withdrawn out of the left or right tail vein with a $27-\mathrm{G}$ needle. Blood was centrifuged at 2,400 $\mathrm{g}$ for $15 \mathrm{~min}$ at room temperature, and serum samples were stored at $-20^{\circ} \mathrm{C}$. Before performing euthanasia, blood was withdrawn intracardiacally under deep anesthesia (170 mg/kg ketamine $+17 \mathrm{mg} / \mathrm{kg}$ xylazine) with a $1-\mathrm{mL}$ syringe and a $24-G$ needle, and then treated as mentioned above. The protocol used for this study was a combination of the approach in previous publications $[25,26]$ which used 3-weekly immunizations ("initiation" and extended this phase by a "maintenance" phase with 4-weekly boosts until the 7th immunization (Fig. 1). Thyroid size, morphology, and histological analysis of the thyroid gland were evaluated as previously reported [24].

Free Thyroxine Levels and Thyrotropin Receptor Antibodies

Serum fT 4 and TSHR-binding inhibiting autoantibodies (TBII) levels were measured with Immulite $2000 \mathrm{XPi}$ (Siemens, Erlangen, Germany) according to the manufacturer's instructions. The reference ranges in humans for $\mathrm{fT} 4$ and TBII are $0.9-1.8 \mathrm{ng} / \mathrm{mL}$ and 0.1-40.0 IU/L, respectively, while the cut-off for the bridge binding TBII immunoassay is 0.55 IU/L. Neat serum samples (approx. 50 $\mu \mathrm{L}$ ) were used to measure fT4 and thyroid-related antibodies.

\section{Bioassay for Blocking TSHR Antibodies}

Levels of serum TSHR-blocking antibodies (TBAb) were measured according to the manufacturer's (Quidel, San Diego, USA) 
Fig. 2. The effect of 7 immunizations (prior to immunization, and at weeks 17 and 27) with the adenovirus carrying the A-subunit of the TSHR in Ad-TSHR mice $(n=8)$ on serum fT4 levels was compared to AdGFP-immunized mice $(n=4)$ and native nonimmunized mice $(n=7)$. Data are shown as mean \pm SEM, ${ }^{\# \#} p<0.001$ AdTSHR-immunized group vs. native nonimmunized mice and Ad-GFP-immunized mice.

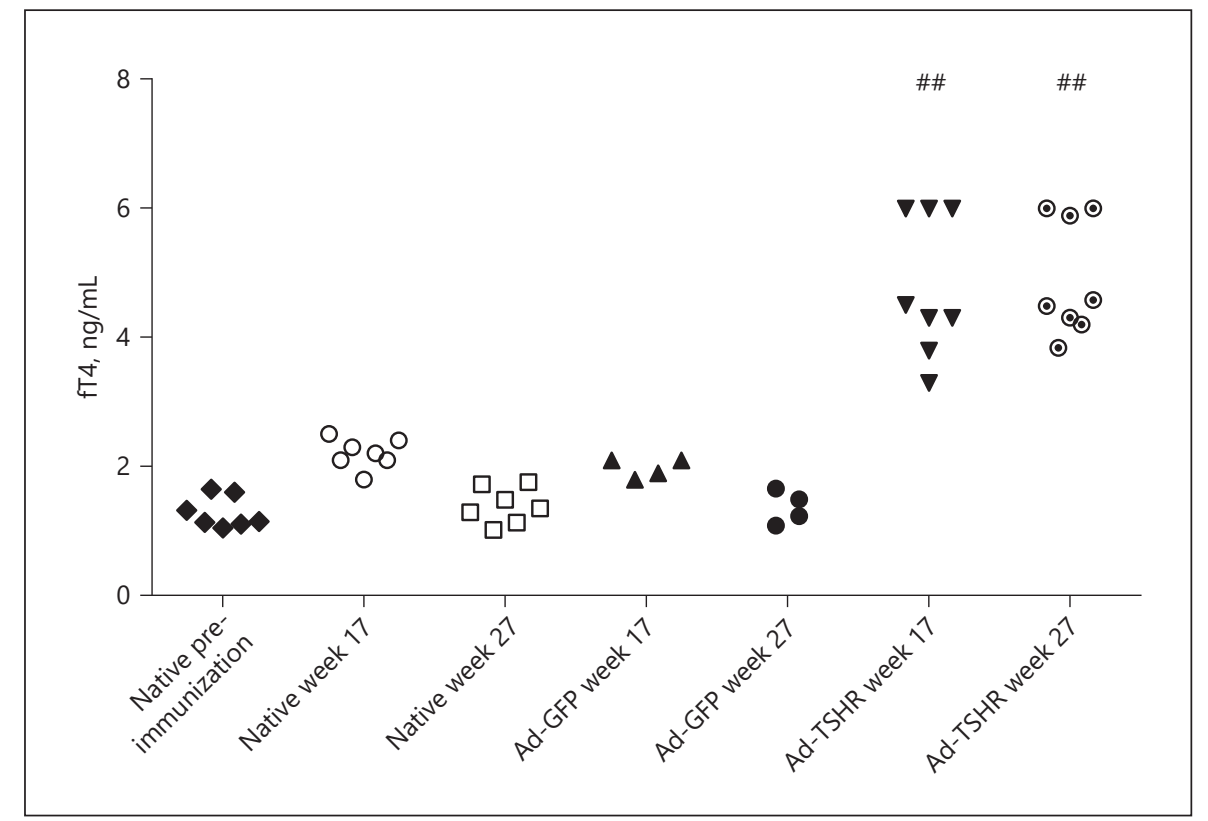

instructions for the CE-marked cell-based bioassay [27, 28]. The cut-off is at $34 \%$ inhibition. All sera were measured in duplicate and data were reported as mean values.

\section{Bioassay for Stimulating TSHR Antibodies}

Levels of serum TSHR-stimulating antibodies (TSAb) were measured with an FDA-cleared cell-based bioassay (Thyretain ${ }^{\circledR}$, Quidel) according to the manufacturer's instructions [29-31]. Briefly, Chinese hamster ovary ( $\mathrm{CHO})-\mathrm{MC} 4$ cells were seeded and grown to confluent cell monolayers in 96-well plates for 15-18 h. Serum samples, as well as positive, reference, and normal controls were diluted 1:11 in reaction buffer, added to the cell monolayers, and each plate was then incubated for $3 \mathrm{~h}$ at $37^{\circ} \mathrm{C}$ and $5 \% \mathrm{CO}_{2}$. Subsequently, the $\mathrm{CHO}-\mathrm{MC} 4$ cells were lysed and the relative light unit values were quantified in a luminometer (Infinite M200; Tecan, Crailsheim, Germany). The assay cut-off is at a specimento-reference-ratio (SRR) of $140 \%$. All sera were measured in duplicate and data were reported as mean values.

\section{Statistical Analyses}

Statistical differences between 2 groups were analyzed by unpaired $t$ test and when comparing $>2$ groups the Kruskal Wallis test was applied using GraphPad Prism software v5.04 (San Diego, CA, USA).

\section{Results}

\section{Free Thyroxine Levels}

Serum fT4 concentrations in all investigated mice are shown in Figure 2. In the native, nonimmunized mice, levels (median [25th percentile; 75 th percentile]) were in the upper normal range prior to immunization
Table 1. Distribution of TSAb, TBAb, and TBII at weeks 17 and 27 in Ad-TSHR-immunized mice $(n=8)$

\begin{tabular}{|c|c|c|c|}
\hline & \multicolumn{2}{|c|}{ Bioassays } & \multirow{2}{*}{$\frac{\text { Binding immunoassay }}{\text { TBII }}$} \\
\hline & TSAb & TBAb & \\
\hline \multicolumn{4}{|l|}{ Week 17} \\
\hline$n=1$ & + & - & + \\
\hline$n=5$ & - & + & + \\
\hline$n=2$ & + & + & + \\
\hline \multicolumn{4}{|l|}{ Week 27} \\
\hline$n=2$ & + & - & + \\
\hline$n=5$ & - & + & + \\
\hline$n=1$ & + & + & + \\
\hline
\end{tabular}

$(1.2 \mathrm{ng} / \mathrm{mL}[1.1 ; 1.6])$, at week $17(2.2 \mathrm{ng} / \mathrm{mL}[2.1 ; 2.4])$, and at week $27(1.4 \mathrm{ng} / \mathrm{mL}[1.1 ; 1.7])$, respectively. In contrast, in Ad-TSHR-immunized mice, fT4 concentrations were markedly higher at weeks $17(4.4 \mathrm{ng} / \mathrm{mL}$ $[3.9 ; 6])$ and $27(4.5 \mathrm{ng} / \mathrm{mL}[4.2 ; 6])$ than in Ad-GFPimmunized mice $(2 \mathrm{ng} / \mathrm{mL}[1.8 ; 2.1]$ and $1.4 \mathrm{ng} / \mathrm{mL}$ $[1.1 ; 1.6])$ at weeks $17(p=0.0008)$ and $27(p=0.001)$, respectively.

\section{Thyrotropin Receptor Antibodies}

TBII measured in a binding bridge immunoassay and $\mathrm{TBAb}$ and TSAb measured in cell-based bioassays are shown in Figure $3 a-c$. The distribution of TBII, TBAb, and TSAb at weeks 17 and 27 in Ad-TSHR-immunized 
Fig. 3. a Scatter plot of TBII prior to immunization, and at weeks 17, 21, and 27 in native nonimmunized mice ( $n=7)$, Ad-GFPimmunized mice $(n=4)$, and Ad-TSHRimmunized mice $(n=8)$. The dashed line indicates the bridge assay cut-off at 0.55 IU/L. Individual values of all investigated mice of each group are shown. ${ }^{\mathrm{IIt}} p<0.0001$ Ad-TSHR-immunized vs. native nonimmunized mice and Ad-GFP-immunized mice. b Scatter plot of TBAb prior to immunization as well as at weeks 17,21 , and 27 in native nonimmunized mice $(n=7)$, Ad-GFP-immunized mice $(n=4)$, and AdTSHR-immunized mice $(n=8)$. The dashed line indicates the TBAb bioassay cut-off at $34 \%$ inhibition. Individual values of all investigated mice of each group are shown. ${ }^{*} p<0.05$ Ad-TSHR-immunized vs. Ad-GFP-immunized mice at weeks 17, 21, and 27, respectively. ${ }^{\#} p<0.005$ Ad-TSHRimmunized vs. native non-immunized mice at weeks 17, 21, and 27, respectively. c Scatter plot of TSAb prior to immunization, and at weeks 17, 21, and 27 in native nonimmunized mice ( $n=7)$, Ad-GFP-immunized mice $(n=4)$, and Ad-TSHR-immunized mice $(n=8)$. The dashed line indicates the TSAb bioassay cut-off at 140\% SRR. Individual values of all investigated mice of each group are shown. ${ }^{*} p<0.05$ Ad-TSHR-immunized vs. Ad-GFP-immunized mice at weeks 17,21 , and 27 , respectively. ${ }^{\# \#} p<0.005$ Ad-TSHR-immunized vs. native nonimmunized mice at weeks 17 , 21 , and 27 , respectively.
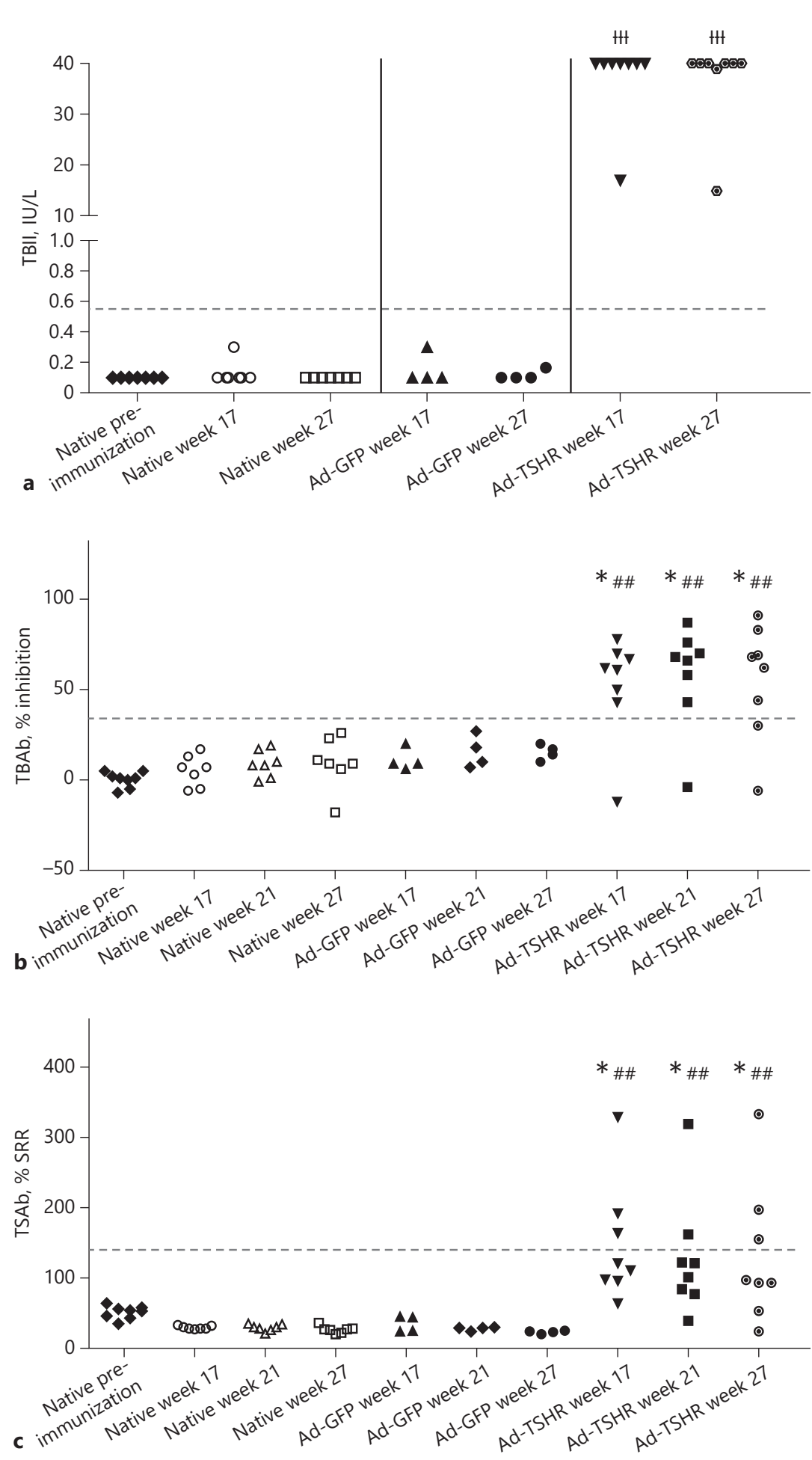
Table 2. TBII, TBAb, and TSAb levels in native nonimmunized, Ad-GFP-immunized, and Ad-TSHR-immunized mice over 27 weeks

\begin{tabular}{|c|c|c|c|c|c|}
\hline & Native (A) & Ad-GFP (B) & Ad-TSHR (C) & $\begin{array}{l}\text { A vs. C } \\
p \text { value }\end{array}$ & $\begin{array}{l}\text { B vs. C } \\
p \text { value }\end{array}$ \\
\hline \multicolumn{6}{|l|}{ Preimmunization } \\
\hline \multicolumn{6}{|l|}{ TBII (IU/L) } \\
\hline Median & 0.1 & & & & \\
\hline 25th; 75th percentiles & $0.1 ; 0.1$ & & & & \\
\hline \multicolumn{6}{|l|}{ TBAb (\% inhibition) } \\
\hline Median & 1 & & & & \\
\hline 25th; 75th percentiles & $-4 ; 4$ & & & & \\
\hline \multicolumn{6}{|l|}{ TSAb (\% SRR) } \\
\hline Median & 54 & & & & \\
\hline 25th; 75th percentiles & $44 ; 58$ & & & & \\
\hline \multicolumn{6}{|l|}{ At week 17} \\
\hline TBII (IU/L) & & & & $<0.0001$ & $<0.0001$ \\
\hline Median & 0.1 & 0.1 & 40 & & \\
\hline 25th; 75 th percentiles & $0.1 ; 0.1$ & $0.1 ; 0.25$ & $40 ; 40$ & & \\
\hline TBAb (\% inhibition) & & & & 0.002 & 0.024 \\
\hline Median & 7 & 9 & 62 & & \\
\hline 25th; 75 th percentiles & $-5 ; 13$ & $7 ; 17$ & $38 ; 69$ & & \\
\hline TSAb (\% SRR) & & & & 0.003 & 0.026 \\
\hline Median & 28 & 35 & 116 & & \\
\hline 25th; 75th percentiles & $28 ; 32$ & $24 ; 45$ & $97 ; 185$ & & \\
\hline \multicolumn{6}{|l|}{ At week 21} \\
\hline TBAb (\% inhibition) & & & & 0.001 & 0.016 \\
\hline Median & 8 & 14 & 67 & & \\
\hline 25th; 75th percentiles & $1 ; 17$ & $8 ; 25$ & $47 ; 75$ & & \\
\hline TSAb (\% SRR) & & & & 0.009 & 0.04 \\
\hline Median & 30 & 29 & 111 & & \\
\hline 25th; 75th percentiles & $26 ; 34$ & $25 ; 30$ & $79 ; 152$ & & \\
\hline \multicolumn{6}{|l|}{ At week 27} \\
\hline TBII (IU/L) & & & & $<0.0001$ & $<0.0001$ \\
\hline Median & 0.1 & 0.1 & 40 & & \\
\hline 25th; 75th percentiles & $0.1 ; 0.1$ & $0.1 ; 0.15$ & $39.18 ; 40$ & & \\
\hline TBAb (\% inhibition) & & & & 0.005 & 0.04 \\
\hline Median & 9 & 16 & 65 & & \\
\hline 25 th; 75 th percentiles & $6 ; 26$ & $11 ; 28$ & $34 ; 80$ & & \\
\hline TSAb (\% SRR) & & & & 0.015 & 0.04 \\
\hline Median & 27 & 24 & 95 & & \\
\hline 25th; 75 th percentiles & $22 ; 28$ & $21 ; 25$ & $63 ; 187$ & & \\
\hline
\end{tabular}

mice is summarized in Table 1 . Serum levels of TBII, TBAb, and TSAb in native, Ad-GFP-, and Ad-TSHR-immunized mice over 27 weeks are shown in Table 2. Interestingly, 3 serum samples from the Ad-TSHR-immunized mice (38\%) showed dual TBAb and TSAb positivity. All TBAb- and/or TSAb-positive or dual-positive (i.e., $\mathrm{TBAb}+\mathrm{TBAb})$ Ad-TSHR-immunized mice were TBIIpositive.

Long-Term Graves’ Model
Thyroid Size and Morphology

All investigated thyroid glands from Ad-TSHR-immunized mice showed enlargement upon macroscopical investigation, similar to that previously found for a protocol of 7 immunizations [24] (Fig. 4a). Mean thyroid volume was $5.3 \pm 0.5 \mathrm{~mm}^{3}$ in Ad-TSHR-immunized mice and $2.2 \pm 0.3 \mathrm{~mm}^{3}$ in Ad-GFP-immunized mice. Microscopy revealed an increased mean thyrocyte length (epithelial cell height) (Fig. 4b). Additionally, hypertrophy 


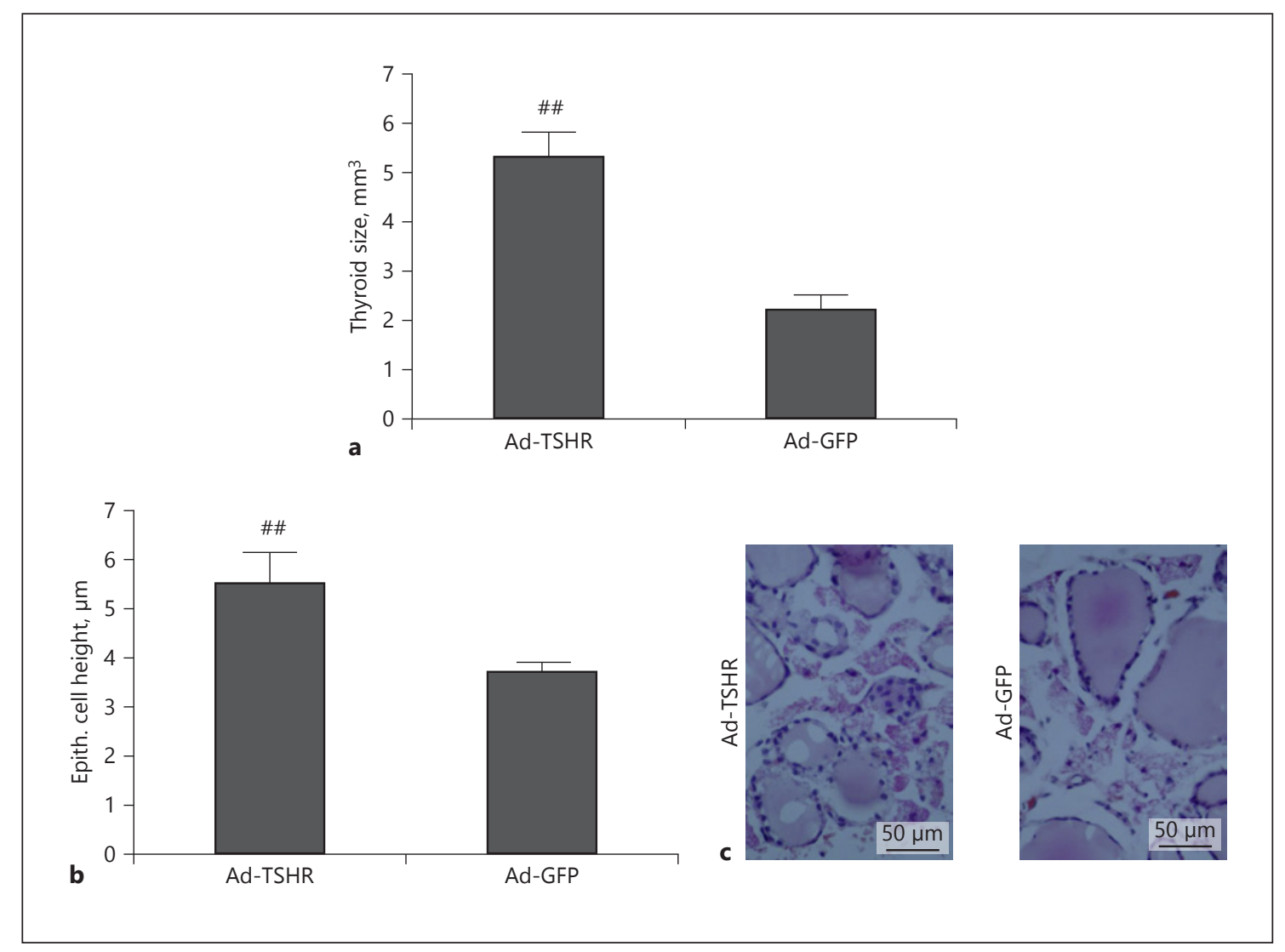

Fig. 4. The effect of 7 immunizations with the adenovirus carrying the A-subunit of the TSHR in Ad-TSHR mice $(n=8)$ on histologically determined thyroid size $(\mathbf{a})$ and thyrocyte length, i.e., epithelial (Epith.) cell height (b) was compared to that in Ad-GFP-immunized mice $(n=4)$. Data are shown as means \pm SEM. ${ }^{\# \#} p<0.005$ AdTSHR-immunized vs. Ad-GFP-immunized mice. c Representative histological sections of the thyroid of AdTSHR-immunized and Ad-GFP-immunized mice.

and in-folding of follicles, many vacuoles in the colloid (Fig. 4c), and richness in the arterioles was observed in Ad-TSHR-immunized mice, in agreement with the earlier study [24]. These changes and colloid volumes were estimated qualitatively.

\section{Discussion}

This study demonstrated that when applying a novel long-term murine model for human GD with repeated, long-term immunizations of the recombinant adenovirus expressing the extracellular A-subunit of human TSHR, functional TSHR-Ab were persistent and highly prevalent in Ad-TSHR-immunized mice over 7 immunizations (i.e., 27 weeks after the first immunization). Therefore, the original protocol of three 3-weekly immunizations was extended, followed by regular 4 -weekly boosts. This led to continuous and sustained production of TBAb and TSAb in the Ad-TSHR-immunized mice, which has not been proven before. Furthermore, and to the best of our knowledge, we report elevated fT4 levels instead of total T4 levels for the first time in any animal model of GD. The fT4 levels in the Ad-TSHR-immunized mice were consistently and significantly higher than those in the Ad-GFPimmunized mice and in the native mice when immunized with $10^{10} \mathrm{pfu}$.

The prevalence of TSAb which was detected by the TSAb luciferase cell-based bioassay in 38\% of Ad-TSHRimmunized mice was lower than that detected by an assay which directly measured mouse serum-induced human TSHR-dependent cAMP increase in CHO cells ( $>90 \%$ of Ad-TSHR-immunized mice after 27 weeks [24]). One reason for this could be the longer induction time of the TSAb reporter gene assay necessary to start the luciferase gene transcription and translation in contrast to the 
cAMP assay. Furthermore, signal amplification in the TSAb luciferase bioassay exhibits a higher sensitivity than the cAMP assay.

We also demonstrated the relevance and clinical utility of measuring functional TSHR-Ab. The bridge immunoassay is a purely binding assay that utilizes a pair of recombinant human TSHRs and measures the total antiTSHR-binding activity [32]. However, exclusive and specific differentiation of TSHR-Ab functionality occurs when using both TBAb/TSAb bioassays subsequent to the immunization with Ad-TSHR. A further advantage for measuring functional TSHR-Ab is to document potential dual-positivity, i.e., the presence of both TBAb and $\mathrm{TSAb}$, in contrast to the binding bridge immunoassay that shows the antibody binding to the antigen without any further differentiation. Finally, the concentration of the functional TSHR-Ab varies in the long-term animal model; this is not observed with the binding assay, which shows constant concentrations during the whole process in immunized mice. Surprisingly, the samples with the highest levels of binding TSHR-Ab measured with the bridge immunoassay were the blocking TSHR-Ab-positive samples, which confirmed the nonspecific character of the bridge binding assay.

When using 2 or 3 adenovirus injections of the recombinant TSHR A-subunit $\left(10^{10} \mathrm{pfu}\right)$ in wild-type and transgenic mice at 3-week intervals, the generation of TSHR$\mathrm{Ab}$ with binding activity was consistently observed after 5 months (20 weeks) in the virus-immunized mice. The potency of the resulting $\mathrm{Ab}$ to stimulate cAMP declined during the course of the experiment (to only $50 \%$ positive at the end), however, and no fT4 elevation or thyrocyte hyperplasia was noted [23, 33]. Macroscopic investigation revealed both increased thyroid sizes as well as consistent and marked thyroid hyperplasia in the Ad-TSHRimmunized mice which had received 7 immunizations of recombinant adenovirus encoding TSHR. Histologically, increased thyroid length, hyperplasia, in-folding of follicles, smaller follicle sizes, and fractioning of thyroid follicles were noted [24].

Interestingly, this adenovirus model is suitable for investigating the effect of potential therapeutic compounds [34]. Repeated administration of novel cyclic peptides, derived from the 8th or the 1st cylindrical loop of the leucine-rich repeat domain of the TSHR in Ad-TSHRimmunized mice, was found to have reduced the thyroid size and normalized the fT4 levels 8 weeks after starting peptide therapy [34].

In conclusion, functional TSHR-Ab measured in cellbased bioassays were found to be highly prevalent in Ad-
TSHR-immunized mice, thus confirming the successful establishment of a novel, long-term animal model for GD. All TBAb- and/or TSAb-positive Ad-TSHR-immunized mice were TBII-positive. The binding bridge immunoassay did not differentiate TSHR-Ab functionality, which confirmed numerous previous reports [32, 3537].

\section{Acknowledgment}

The authors thank Miss Lara Frommer, Master of Science, JGU Thyroid Lab, Mainz, Germany, for her appreciated editorial assistance.

\section{Statement of Ethics}

All applicable international, national, and institutional guidelines for the care and use of animals were followed. All animal experiments were approved by the local animal welfare authority and the ethics committee of the "Regierung von Oberbayern" (Government Upper Bavaria), Munich, Germany (No. 55.2-1-54-2531-2512), and were carried out according to European Commission guidelines. All procedures performed in studies involving animals were in accordance with the ethics standards of the institution or practice at which they were conducted.

\section{Conflict of Interest Statement}

T.D., C.W., and M.K. have nothing to disclose. H.-P.H., J.F., and M.U. are employees of the biotech company AdvanceCor $\mathrm{GmbH}$, Germany. G.J.K. consults for Quidel, USA.

\section{Funding Sources}

The JGU Medical Center has received research-associated funding from Quidel, USA and AdvanceCor, Germany.

\section{Author Contributions}

G.J.K. and M.U. initiated the project. T.D., G.J.K., and M.U. wrote the manuscript. H.-P.H., J.F., C.W., and M.K. contributed to data collection and documentation. All coauthors critically reviewed and approved the manuscript. 


\section{References}

1 Dittmar M, Kahaly GJ. Immunoregulatory and susceptibility genes in thyroid and polyglandular autoimmunity. Thyroid. 2005 Mar; 15(3):239-50.

2 Diana T, Brown RS, Bossowski A, Segni M, Niedziela M, König J, et al. Clinical relevance of thyroid-stimulating autoantibodies in pediatric graves' disease-a multicenter study. J Clin Endocrinol Metab. 2014 May;99(5): 1648-55.

3 Ponto KA, Diana T, Binder H, Matheis N, Pitz $\mathrm{S}$, Pfeiffer $\mathrm{N}$, et al. Thyroid-stimulating immunoglobulins indicate the onset of dysthyroid optic neuropathy. J Endocrinol Invest. 2015 Jul;38(7):769-77.

4 Kiefer FW, Klebermass-Schrehof K, Steiner M, Worda C, Kasprian G, Diana T, et al. Fetal/ Neonatal Thyrotoxicosis in a Newborn From a Hypothyroid Woman With Hashimoto Thyroiditis. J Clin Endocrinol Metab. 2017 Jan;102(1):6-9.

5 Diana T, Daiber A, Oelze M, Neumann S, Olivo PD, Kanitz M, et al. Stimulatory TSH-Receptor Antibodies and Oxidative Stress in Graves Disease. J Clin Endocrinol Metab. 2018 Oct; 103(10):3668-77.

6 Kahaly GJ, Wüster C, Olivo PD, Diana T. High Titers of Thyrotropin Receptor Antibodies Are Associated with Orbitopathy in Patients with Graves Disease. J Clin Endocrinol Metab. 2019 Jul;104(7):2561-8.

7 Kahaly GJ, Diana T, Olivo PD. Tsh Receptor Antibodies: Relevance \& Utility. Endocr Pract. 2020 Jan;26(1):97-106.

8 Diana T, Krause J, Olivo PD, König J, Kanitz M, Decallonne B, et al. Prevalence and clinical relevance of thyroid stimulating hormone receptor-blocking antibodies in autoimmune thyroid disease. Clin Exp Immunol. 2017 Sep; 189(3):304-9.

9 Diana T, Olivo PD, Kahaly GJ. Thyrotropin Receptor Blocking Antibodies. Horm Metab Res. 2018 Dec;50(12):853-62.

10 Lytton SD, Ponto KA, Kanitz M, Matheis N, Kohn LD, Kahaly GJ. A novel thyroid stimulating immunoglobulin bioassay is a functional indicator of activity and severity of Graves' orbitopathy. J Clin Endocrinol Metab. 2010 May;95(5):2123-31.

11 Kampmann E, Diana T, Kanitz M, Hoppe D, Kahaly GJ. Thyroid Stimulating but Not Blocking Autoantibodies Are Highly Prevalent in Severe and Active Thyroid-Associated Orbitopathy: A Prospective Study. Int J Endocrinol. 2015;2015:678194.

12 Kahaly GJ. Bioassays for TSH Receptor Antibodies: quo Vadis? Eur Thyroid J. 2015 Mar; $4(1): 3-5$.

13 Diana T, Kahaly GJ. Thyroid Stimulating Hormone Receptor Antibodies in Thyroid Eye Disease-Methodology and Clinical Applications. Ophthal Plast Reconstr Surg. 2018 Jul/Aug;34(4S Suppl 1):S13-9.
14 Kahaly GJ, Diana T, Kanitz M, Frommer L, Olivo PD. Prospective Trial of Functional Thyrotropin Receptor Antibodies in Graves Disease. J Clin Endocrinol Metab. 2020 Apr; 105(4): 105.

15 Zhao SX, Tsui S, Cheung A, Douglas RS, Smith TJ, Banga JP. Orbital fibrosis in a mouse model of Graves' disease induced by genetic immunization of thyrotropin receptor cDNA. J Endocrinol. 2011 Sep;210(3): 369-77.

16 Moshkelgosha S, So PW, Deasy N, Diaz-Cano $S$, Banga JP. Cutting edge: retrobulbar inflammation, adipogenesis, and acute orbital congestion in a preclinical female mouse model of Graves' orbitopathy induced by thyrotropin receptor plasmid-in vivo electroporation. Endocrinology. 2013 Sep;154(9):3008-15.

17 Banga JP, Moshkelgosha S, BerchnerPfannschmidt U, Eckstein A. Modeling Graves' Orbitopathy in Experimental Graves' Disease. Horm Metab Res. 2015 Sep;47(10):797-803.

18 Costagliola S, Many MC, Denef JF, Pohlenz J, Refetoff S, Vassart G. Genetic immunization of outbred mice with thyrotropin receptor cDNA provides a model of Graves' disease. J Clin Invest. 2000 Mar;105(6):803-11.

19 Yamada M, Li AW, West KA, Chang CH, Wall JR. Experimental model for ophthalmopathy in BALB/c and outbred (CD-1) mice genetically immunized with G2s and the thyrotropin receptor. Autoimmunity. 2002 Sep; 35(6):403-13

20 Shimojo N, Kohno Y, Yamaguchi K, Kikuoka $\mathrm{S}$, Hoshioka A, Niimi H, et al. Induction of Graves-like disease in mice by immunization with fibroblasts transfected with the thyrotropin receptor and a class II molecule. Proc Natl Acad Sci USA. 1996 Oct;93(20):11074-9.

21 Ungerer M, Faßbender J, Li Z, Münch G, Holthoff HP. Review of Mouse Models of Graves' Disease and Orbitopathy-Novel Treatment by Induction of Tolerance. Clin Rev Allergy Immunol. 2017 Apr;52(2):18293.

22 Kaneda T, Honda A, Hakozaki A, Fuse T, Muto A, Yoshida T. An improved Graves' disease model established by using in vivo electroporation exhibited long-term immunity to hyperthyroidism in BALB/c mice. Endocrinology. 2007 May;148(5):2335-44.

23 McLachlan SM, Aliesky HA, Chen CR, Rapoport B. Role of self-tolerance and chronic stimulation in the long-term persistence of adenovirus-induced thyrotropin receptor antibodies in wild-type and transgenic mice. Thyroid. 2012 Sep;22(9):931-7.

24 Holthoff HP, Goebel S, Li Z, Faßbender J, Reimann A, Zeibig S, et al. Prolonged TSH receptor A subunit immunization of female mice leads to a long-term model of Graves' disease, tachycardia, and cardiac hypertrophy. Endocrinology. 2015 Apr;156(4):157789.
25 Chen CR, Pichurin P, Nagayama Y, Latrofa F, Rapoport B, McLachlan SM. The thyrotropin receptor autoantigen in Graves disease is the culprit as well as the victim. J Clin Invest. 2003 Jun;111(12):1897-904.

26 Gilbert JA, Kalled SL, Moorhead J, Hess DM, Rennert P, Li Z, et al. Treatment of autoimmune hyperthyroidism in a murine model of Graves' disease with tumor necrosis factorfamily ligand inhibitors suggests a key role for $B$ cell activating factor in disease pathology. Endocrinology. 2006 Oct;147(10):4561-8.

27 Li Y, Kim J, Diana T, Klasen R, Olivo PD, Kahaly GJ. A novel bioassay for anti-thyrotrophin receptor autoantibodies detects both thyroid-blocking and stimulating activity. Clin Exp Immunol. 2013 Sep;173(3):390-7.

28 Diana T, Li Y, Olivo PD, Lackner KJ, Kim H, Kanitz M, et al. Analytical Performance and Validation of a Bioassay for Thyroid-Blocking Antibodies. Thyroid. 2016 May;26(5): 734-40.

29 Lytton SD, Li Y, Olivo PD, Kohn LD, Kahaly GJ. Novel chimeric thyroid-stimulating hormone-receptor bioassay for thyroid-stimulating immunoglobulins. Clin Exp Immunol. 2010 Dec;162(3):438-46.

30 Leschik JJ, Diana T, Olivo PD, König J, Krahn U, Li Y, et al. Analytical performance and clinical utility of a bioassay for thyroid-stimulating immunoglobulins. Am J Clin Pathol. 2013 Feb;139(2):192-200.

31 Diana T, Kanitz M, Lehmann M, Li Y, Olivo PD, Kahaly GJ. Standardization of a bioassay for thyrotropin receptor stimulating autoantibodies. Thyroid. 2015 Feb;25(2):169-75.

32 Allelein S, Diana T, Ehlers M, Kanitz M, Hermsen D, Schott M, et al. Comparison of a Bridge Immunoassay with Two Bioassays for Thyrotropin Receptor Antibody Detection and Differentiation. Horm Metab Res. 2019 Jun;51(6):341-6.

33 McLachlan SM, Aliesky H, Chen CR, Rapoport B. Long term persistence of thyrotropin receptor antibodies in wild-type and transgenic mice in a Graves' disease model. Thyroid. 2012, Online ahead of print.

34 Faßbender J, Holthoff HP, Li Z, Ungerer M. Therapeutic Effects of Short Cyclic and Combined Epitope Peptides in a Long-Term Model of Graves' Disease and Orbitopathy. Thyroid. 2019 Feb;29(2):258-67.

35 Diana T, Wüster C, Kanitz M, Kahaly GJ. Highly variable sensitivity of five binding and two bio-assays for TSH-receptor antibodies. J Endocrinol Invest. 2016 Oct;39(10):1159-65.

36 Kahaly GJ, Diana T. TSH Receptor Antibody Functionality and Nomenclature. Front Endocrinol (Lausanne). 2017 Feb;8:28.

37 Diana T, Wüster C, Olivo PD, Unterrainer A, König J, Kanitz M, et al. Performance and Specificity of 6 Immunoassays for TSH Receptor Antibodies: A Multicenter Study. Eur Thyroid J. 2017 Sep;6(5):243-9. 